Article

\title{
Synthesis of Trichodermin Derivatives and Their Antimicrobial and Cytotoxic Activities
}

\author{
Javier E. Barúa ${ }^{1,2}$, Mercedes de la Cruz ${ }^{3}{ }^{-}$, Nuria de Pedro ${ }^{3}$, Bastien Cautain ${ }^{3}$, Rosa Hermosa ${ }^{4}$, \\ Rosa E. Cardoza $\left.{ }^{5}{ }^{(}\right)$, Santiago Gutiérrez ${ }^{5}{ }^{\circledR}$, Enrique Monte ${ }^{4}$, Francisca Vicente ${ }^{3}$ \\ and Isidro G. Collado $2, *$ (i) \\ 1 Biological Chemistry Department, Chemistry Science Faculty, National University of Asunción, Ruta Mcal. \\ Estigarribia Km 11.5, San Lorenzo 2160, Paraguay; javierbarua@qui.una.py \\ 2 Department of Organic Chemistry, Campus of Puerto Real, Science Faculty, University of Cádiz, \\ 11510 Puerto Real, Cádiz, Spain \\ 3 Fundación Medina, Avda. del Conocimiento 34, Armilla, 18016 Granada, Spain; \\ mercedes.delacruz@medinaandalucia.es (M.d.l.C.); nuri_dp@hotmail.es (N.d.P.); \\ bastien.cautain@medinaandalucia.es (B.C.); francisca.vicente@medinaandalucia.es (F.V.) \\ 4 Department of Microbiology and Genetics, Spanish-Portuguese Institute for Agricultural Research (CIALE), \\ University of Salamanca, Campus of Villamayor, Rio Duero 12, 37185 Salamanca, Spain; rhp@usal.es (R.H.); \\ emv@usal.es (E.M.) \\ 5 University of León, Campus of Ponferrada, Superior and Technical Universitary School of Agricultural \\ Engineers, Area of Microbiology, Avda. Astorga s/n, 24400 Ponferrada, Spain; \\ re.cardoza@unileon.es (R.E.C.); s.gutierrez@unileon.es (S.G.) \\ * Correspondence: isidro.gonzalez@uca.es; Tel.: +34-956-012768
}

Received: 1 October 2019; Accepted: 21 October 2019; Published: 22 October 2019

check for updates

\begin{abstract}
Trichothecene mycotoxins are recognized as highly bioactive compounds that can be used in the design of new useful bioactive molecules. In Trichoderma brevicompactum, the first specific step in trichothecene biosynthesis is carried out by a terpene cyclase, trichodiene synthase, that catalyzes the conversion of farnesyl diphosphate to trichodiene and is encoded by the tri5 gene. Overexpression of tri5 resulted in increased levels of trichodermin, a trichothecene-type toxin, which is a valuable tool in preparing new molecules with a trichothecene skeleton. In this work, we developed the hemisynthesis of trichodermin and trichodermol derivatives in order to evaluate their antimicrobial and cytotoxic activities and to study the chemo-modulation of their bioactivity. Some derivatives with a short chain at the C-4 position displayed selective antimicrobial activity against Candida albicans and they showed MIC values similar to those displayed by trichodermin. It is important to highlight the cytotoxic selectivity observed for compounds 9,13 , and 15 , which presented average $\mathrm{IC}_{50}$ values of $2 \mu \mathrm{g} / \mathrm{mL}$ and were cytotoxic against tumorigenic cell line MCF-7 (breast carcinoma) and not against Fa2N4 (non-tumoral immortalized human hepatocytes).
\end{abstract}

Keywords: trichothecene; sesquiterpenes; tri genes; synthesis; antimicrobial; cytotoxic bioactivity

\section{Introduction}

Natural products (NPs, secondary metabolites) are an invaluable source of inspiration in drug design and development. Having evolved over several millennia to acquire specific ligand-protein binding motifs, their structures cover a wide range of biologically relevant chemical space that cannot be efficiently explored by synthetic compounds in commercially available screening libraries $[1,2]$. Of all new drugs approved between 1981 and $2014(n=1562), 50 \%$ are natural products, are derived from natural products, or are synthetic molecules inspired by or that mimic natural products [3]. Terpenoids are the largest class of NPs, with about $60 \%$ of NP diversity originating from the terpene 
pathway [4]. All terpenes are derived from the repetitive fusion of branched five-carbon units based on an isopentene skeleton, and most of the chemical intermediates in their biosynthetic pathway are known [5]. Typical structures contain carbon skeletons represented by (C5)n and are classified as hemiterpenes (C5), monoterpenes (C10), sesquiterpenes (C15), diterpenes (C20), sesterterpenes (C25), triterpenes (C30), and tetraterpenes (C40) [6].

Trichothecenes are a particular type of sesquiterpene which are a family of metabolites that have mainly been isolated from species of Fusarium and certain other fungal genera like Cephalosporium, Isaria, Microcyclospora, Myrothecium, Spicellum, Stachybotrys, Trichoderma, and Trichothecium. The biosynthesis of trichothecenes is well documented and has been the focus of several detailed reviews [7,8]. All trichothecenes contain a common skeleton or tricyclic ring that typically contains an epoxide between the C-12 and C-13 carbons and a varying number of hydroxyl or acetoxy groups [9]. This sesquiterpene family exhibits cytotoxic activity against different eukaryotes cell lines by induction of apoptosis [10], and also acts as a fungicide [11], an immunosuppressant [12] and a neurotoxin [13].

The biosynthetic pathway of trichothecenes has been widely studied in Fusarium species [14] and has recently been described in Trichoderma species [15,16]. In both cases, the genes involved are organized in clusters. The cyclization of farnesyl diphosphate to trichodiene, the first step in the biosynthetic pathway of approximately 150 different toxic trichothecenes, is catalyzed by the enzyme trichodiene synthase which is encoded by the tri5 gene. This tri5 gene has been isolated and characterized in Trichoderma brevicompactum, the only Trichoderma species that is capable of producing trichodermin (1) [17] and overexpression of the tri5 gene has shown that it is involved in the production of $\mathbf{1}$ and in the antifungal activity exhibited by T. brevicompactum [5].

Trichodermin (1) is a member of a family of sesquiterpene metabolites that possesses an olefinic group at positions C-9 and C-10 and an epoxide group between C-12 and C-13, on a trichothecene skeleton, characterizing it as a 12,13-epoxytrichothecene [18]. This compound diffuses rapidly through the cell membrane and binds to the eukaryotic ribosome to inhibit the translation of proteins by means of interaction with the peptidyl transferase [19]. It has been shown that trichodermin (1) is a potent inhibitor of protein synthesis in mammals and its inhibitory activity requires the presence of both the C9-C10 olefinic group and the characteristic C12-C13 epoxide group [9]. Trichodermin (1) has also exhibited potent antimicrobial activity against filamentous fungi and yeasts and bacteria [5]. In these studies, the overexpression of the tri5 gene resulted in an increase of the level of transcription of three other trichothecene genes, tri4, tri6, and tri10 [20].

In view of the broad biological activity shown and the pharmacological potential inherent in the chemical structure of $\mathbf{1}$, this work deals with the synthesis of trichodermin derivatives to study the potential chemo-modulation of bioactivity and to evaluate their antimicrobial and cytotoxic activity against a panel of prokaryotic and eukaryotic organisms and different types of cellular lines, respectively, through an analysis of the relationship between the chemical structure and activity of these derivatives.

\section{Results and Discussion}

\subsection{Synthesis of Trichodermin Derivatives}

The potency and broad biological activity shown by trichodermin (1) sparked our interest in amassing adequate amounts of this molecule to complete a study of its biological activity and to perform chemical transformations on the $\mathbf{1}$ skeleton with a view to modulating or enhancing this biological activity. Several efforts have been made to modulate the activity of trichothecenes as antifungal agents [21-23] with promising results. Total synthesis of trichodermin (1) [24] and trichodermol (2) $[25,26]$ has been proposed. However, this involves several reaction steps, making it expensive and inefficient.

In recent years, we have worked on obtaining transformants of T. brevicompactum in order to study the functionality of the genes involved in the biosynthesis of trichothecenes and to obtain mutants to 
efficiently produce large quantities of trichodermin (1) or trichodermol (2), the final precursor of $\mathbf{1}$ in its biosynthetic pathway. To that end, our group has analyzed the production of trichothecenes by transformants overexpressing the tri5 gene. We found that trichodermin (1) production in these strains increased dramatically compared to that of the parent strain, achieving yields up to $32.3 \%$ of dry crude extract compared to the wild strain that reached levels of $11.3 \mathrm{mg} / \mathrm{mL}$ after 14 days of fermentation [5].

With this knowledge, and to obtain adequate amounts of trichodermin (1) needed for the synthesis of its derivatives, we fermented T. brevicompactum IBT40841-derived tri5-overexpressing transformant Tb41tri5 [5] in PDB medium for 14 days, which produced, by extraction of the fermentation broth with ethyl acetate, $1.4 \mathrm{~g}$ of crude extract. This was preliminarily analyzed by TLC and ${ }^{1} \mathrm{H}-\mathrm{NMR}$. From the chromatographic separation of the crude extract, a compound 1-enriched fraction was obtained, which was then purified by HPLC and characterized by extensive NMR experiments to yield $815 \mathrm{mg}$ of the pure compound.

Scheme 1 shows the chemical transformations performed on $\mathbf{1}$. Modifications were made on the olefin located on the C9-C10 carbons and on the C12-C13 epoxide. Furthermore, a group of nine compounds with different substituents at the $\mathrm{C} 4$ carbon were prepared by esterifying the hydroxyl group at this position. All the products obtained were purified by HPLC, and their structures were elucidated by spectroscopic techniques.
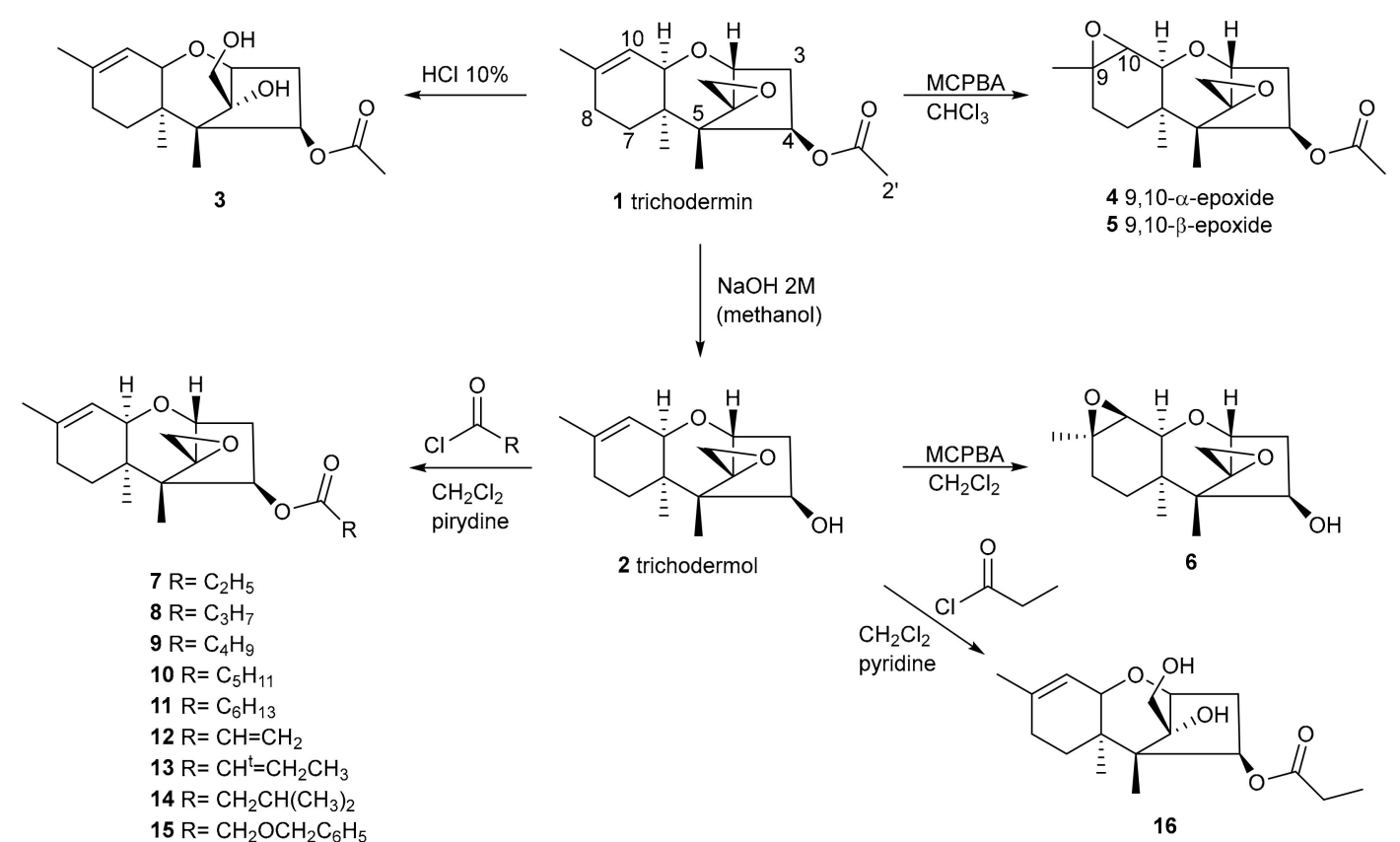

Scheme 1. Chemical transformations carried out on trichodermin (1) and trichodermol (2) for the preparation of compounds $\mathbf{3 - 1 6 .}$

Product 3 was prepared at a yield of $49 \%$ by treating 1 with a stirred aqueous solution of $\mathrm{HCl}$ $(10 \%)$ for $15 \mathrm{~h}$. Its molecular formula was confirmed by High Resolution Mass Spectrometry (HRMS) where an $\mathrm{m} / \mathrm{z}$ ion $\left[\mathrm{C}_{17} \mathrm{H}_{26} \mathrm{O}_{5}+\mathrm{H}\right]^{+} 311.1837$ was observed. Furthermore, the opening of the epoxide at C12-C13 of 1 was revealed by the signals in its ${ }^{1} \mathrm{H}-\mathrm{NMR}$ spectrum at $\delta 3.88 \mathrm{ppm}$, which integrated for $2 \mathrm{H}$ corresponding to the two $\mathrm{H}-13$ protons.

Products 4 and 5 were prepared by treating $\mathbf{1}$, dissolved in chloroform, with $m$-chloroperbenzoic acid (MCPBA). The reaction yielded two epoxidation products corresponding to C9-C-10- $\alpha$-epoxide (4) and the epoxide with $\beta$ orientation (5), with yields of $7.2 \%$ and $82.3 \%$, respectively. The loss of the signals corresponding to the C9-C-10 olefin of trichodermin (1) was confirmed by means of ${ }^{1} \mathrm{H}-\mathrm{NMR}$ and ${ }^{13} \mathrm{C}$-NMR spectroscopy. HRMS data confirmed the expected molecular formula $\mathrm{C}_{17} \mathrm{H}_{24} \mathrm{O}_{5}$ for both products. Lastly, stereochemistry was assigned based on observed nuclear Overhauser effect 
(NOE) interactions. Thus, in NOESY-1D experiments performed on 5, irradiation of H-10 produced enhancements at $\mathrm{H}-11, \mathrm{H}-15$, and $\mathrm{H}-16$, determining the $\beta$ orientation of the epoxide for this derivative.

Trichodermol (2) was obtained from the alkaline treatment of $\mathbf{1}$ by stirring in a methanolic solution of $\mathrm{NaOH}(2 \mathrm{M})$. The reaction product 2 was confirmed by comparing its NMR signals with those described in the literature [27]. The loss of the acetyl group at position C-4 left 4-OH free, an easily accessible function for the introduction of various substituents. This product was used to prepare derivatives 6-16.

Product 6 was prepared from trichodermol (2) by means of an epoxidation reaction similar to the one described for 4 and 5. All its physical constants were concordant with the proposed structure.

Products 7-15 were prepared from the esterification of the hydroxyl group at C-4 of compound 2 , with the corresponding acyl chlorides in the presence of pyridine. Good yields of all the products were obtained, and their spectroscopic data coincided with the proposed structures. Product 16 was obtained from a reaction of $\mathbf{2}$ with an excess of propanoyl chloride in the presence of pyridine.

The acid medium, probably due to a large excess of the reagent, led to the opening of the 12,13-epoxide of $\mathbf{2}$, simultaneously with the introduction of a propanoyl group at position C-4. The mass spectrum showed an ion $m / z 347.1830$ (calculated for $\mathrm{C}_{18} \mathrm{H}_{28} \mathrm{O}_{5} \mathrm{Na}[\mathrm{M}+\mathrm{Na}]^{+}$347.1834), verifying the expected molecular formula.

\subsection{Evaluation of the Cytotoxic and Antimicrobial Activity of Trichodermin (1) Derivatives}

Antimicrobial and cytotoxic activity tests were performed against a panel of microorganisms and human cell lines to evaluate the biological activity of trichodermin (1), trichodermol (2), and derivatives 3-16, respectively. Table 1 summarizes the results of the antimicrobial activity expressed as Minimum Inhibitory Concentrations (MIC). None of the compounds showed significant activity against Acinetobacter baumannii, Pseudomonas aeruginosa, Staphylococcus aureus, or Bacillus subtilis. These results are presented as Supplementary Materials (Table S2). Compounds 9-11 mildly inhibited the growth of Escherichia coli 5746.

Table 1. Antimicrobial activity of compounds 1, 2, 7-9, and 10-15. The results are expressed as MIC in $\mu \mathrm{g} / \mathrm{mL}$.

\begin{tabular}{|c|c|c|c|}
\hline Entry & E. coli MB5746 & MRSA MB5393 & C. albicans MY1055 \\
\hline 1 & $>64$ & $>64$ & $<4$ \\
\hline 2 & $>64$ & $>64$ & $8-16$ \\
\hline 7 & $>64$ & $>64$ & $16-32$ \\
\hline 9 & 64 & $>64$ & $4-8$ \\
\hline 10 & 32 & $>64$ & 8 \\
\hline 11 & 32 & $>64$ & $>64$ \\
\hline 12 & $>64$ & $>64$ & 4 \\
\hline 13 & $>64$ & $>64$ & 4 \\
\hline 14 & $>64$ & $>64$ & $8-16$ \\
\hline 15 & $>64$ & $>64$ & 8 \\
\hline
\end{tabular}

MRSA = Methicillin-resistant S. aureus. MIC = minimal inhibitory concentration.

However, as was expected [5], trichodermin (1) exhibited high inhibition against the yeast Candida albicans $(<4 \mu \mathrm{g} / \mathrm{mL})$. Compounds 2,7 , and 14 exhibited moderate activity $(8-32 \mu \mathrm{g} / \mathrm{mL})$, while the activity of compounds $\mathbf{9}, \mathbf{1 0}$, and 15 can be considered interesting with values between $4-8 \mu \mathrm{g} / \mathrm{mL}$. Special mention should be made of the activity of compounds 12 and 13 with values of $4 \mu \mathrm{g} / \mathrm{mL}$, the most active of the series except for trichodermin (1). Compounds 9 and 12 were previously evaluated in antifungal assays against Botrytis cinerea, Peronophythora litchii, Rhizoctonia solani, Sclerotonia sclerotiorum, and Magnaporthe grisea [21]. 
In other studies, compound $\mathbf{1 0}$ exhibited good antifungal activity against Ustilaginoidea virens, $R$. solani, and M. grisea [22].

The specificity of the activity of the compounds herein described against $C$. albicans should be highlighted. They exhibited good inhibition activity against this yeast and low or no activity against the bacterial groups. A comparison of activities and chemical structures showed that the hydroxyl at C-4 must be esterified with a short-chain ester. However, the presence of a double bond at C-2' in 12 and 13 produces an increase in biological activity close to 1. Compounds 3-6 and 16 completely lost the inhibitory capacity of their precursor trichodermin (1), confirming that both the 12,13-epoxide group and the C9-C10 double bond play a fundamental role in the toxicity of these compounds [28].

Table 2 summarizes the results of the cytotoxic effect observed from trichothecene derivatives on different human cell lines. The results are presented as $\mathrm{IC}_{50}$ in $\mu \mathrm{g} / \mathrm{mL}$, measured after $24 \mathrm{~h}$ of incubation. None of the compounds showed significant cytotoxic activity against the A549 (lung carcinoma) or HT29 (colon carcinoma) lines after $24 \mathrm{~h}$ of incubation (Table S3). Trichodermin (1) showed intense cytotoxic activity against the MCF-7 line (breast carcinoma), and moderately inhibited RCC4-VA (renal carcinoma) and Fa2N4 (immortalized hepatocytes). Unfortunately, this compound exhibited little specificity in terms of its cytotoxic activity, acting indistinctly against both the carcinoma lines and the non-tumoral Fa2N4 line. It is well known that trichodermin is a very potent inhibitor of protein synthesis [29]. However, it is important to highlight the cytotoxicity of derivatives 9, 10, 12, 13, and 15 with approximate $\mathrm{IC}_{50}$ values of between $2-4 \mu \mathrm{g} / \mathrm{mL}$. This can be considered promising as they were selective against the tumorigenic cell line MCF-7, without affecting the non-tumor line Fa2N4.

Table 2. Cytotoxicity of compounds 1, 2, 7, 9-15 in different human cell lines, measured at $24 \mathrm{~h}$ of incubation. $\mathrm{IC}_{50}(\mu \mathrm{g} / \mathrm{mL})$.

\begin{tabular}{cccccc}
\hline Entry & HepG2 & MCF-7 & RCC4-VA & RCC4-VHL & Fa2N4 \\
\hline $\mathbf{1}$ & $>20$ & $<1.25$ & 14.19 & $>20$ & 12.09 \\
$\mathbf{2}$ & $>20$ & 4.42 & $>20$ & $>20$ & $>20$ \\
$\mathbf{7}$ & $>20$ & 13.52 & $>20$ & $>20$ & $>20$ \\
$\mathbf{9}$ & $>20$ & 1.93 & $>20$ & $>20$ & $>20$ \\
$\mathbf{1 0}$ & 14.20 & 3.59 & $>20$ & $>20$ & $>20$ \\
$\mathbf{1 1}$ & $>20$ & 11.26 & $>20$ & $>00$ & $>20$ \\
$\mathbf{1 2}$ & $>20$ & 3.78 & 6.02 & $>20$ & $>20$ \\
$\mathbf{1 3}$ & 17.48 & 2.15 & $>20$ & $>20$ & $>20$ \\
$\mathbf{1 4}$ & $>20$ & 5.22 & 17.14 & 20 & $>20$ \\
$\mathbf{1 5}$ & $>20$ & 2.03 &
\end{tabular}

HepG2 = liver cancer (CCL-8065); MCF-7 = breast carcinoma (HTB-22); RCC4-VA and -VHL = renal carcinoma; Fa2N4 = immortalized human hepatocytes.

A natural product called 8-deoxytrichothecin (17) was isolated from Trichothecium roseum [30] and Spicellum roseum [31,32] and induced the accumulation of glucosylceramide (GlcCer) and simultaneous reduction in the formation of lactosylceramide (LacCer) in complex gangliosides in primary cultured neurons [33]. It also significantly reduced the cell viabilities of HL-60, SMMC-7721, A549, MCF-7 and SW480 cell lines [34]. Compound $\mathbf{1 3}$ is an isomer of $\mathbf{1 7}$ with an E configuration in the double bond $\mathrm{C} 2^{\prime}-\mathrm{C}^{\prime}$.

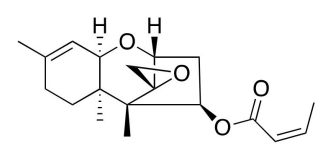

17 8-deoxytrichothecin

These results lead to the proposal of new chemical transformations that enhance the activities of these derivatives. Compared to antimicrobial activity results, the high toxicity of $\mathbf{1}$ against eukaryotic cells can be confirmed, with no noticeable effect on bacteria. 
Compounds 3 and $\mathbf{1 6}$ lost all their activity in all the cell lines tested. These derivatives lost the 12,13-epoxide group of trichodermin (1), confirming that the presence of this group is key to the activity of these trichothecenes. Likewise, $\mathbf{5}$ is inactive under the conditions tested, demonstrating the importance of the C9-C10 double bond in the activity of these trichothecenes. Cell line MCF-7 proved to be especially sensitive to several of the compounds tested. Trichodermol (2) was less active compared to trichodermin (1) due to the loss of the acetyl group, although it still exhibited good activity. Derivatives 7-15, obtained by the esterification of $\mathbf{2}$ at $\mathrm{C} 4-\mathrm{OH}$, all have good $\mathrm{IC}_{50}$ values, especially compound 9 (4-pentanoyltrichodermol) with activity of $1.93 \mu \mathrm{g} / \mathrm{mL}$, the most active of this series, followed by compounds $\mathbf{1 5}(2.03 \mu \mathrm{g} / \mathrm{mL})$ and $\mathbf{1 3}(2.15 \mu \mathrm{g} / \mathrm{mL})$.

\section{Experimental Section}

\subsection{General}

Unless otherwise noted, materials and reagents were obtained from commercial suppliers and were used without further purification. Air- and moisture-sensitive reactions were performed under an argon atmosphere. Optical rotations were determined on a Perkin-Elmer 341 polarimeter (Perkin-Elmer, Seville, Spain). IR spectra were recorded on a Perkin-Elmer Spectrum BX FT-IR spectrophotometer (Perkin-Elmer, Seville, Spain). ${ }^{1} \mathrm{H}$ and ${ }^{13} \mathrm{C}-\mathrm{NMR}$ spectra were obtained on a Varian INOVA $400 \mathrm{MHz}$ NMR spectrometer (Varian, Palo Alto, CA, USA) using tetramethylsilane as an internal reference. NMR assignments were made using a combination of $1 \mathrm{D}$ and 2D techniques and, where appropriate, by comparison with assignments available in the literature for previously described compounds. High-Resolution Mass Spectroscopy (HRMS) was performed with a QTOF mass spectrometer in positive ion ESI or APCI APGC $^{+}$for sample analyses using GC chromatography (Waters, Manchester, UK). HPLC was performed with a Hitachi/Merck L-6270 device equipped with a UV-VIS detector (L 4250) and a differential refractometer detector (RI-71) (VWR, Barcelona, Spain). TLC was performed on a Merck Kieselgel $60 \mathrm{~F}_{254}, 0.2 \mathrm{~mm}$ thick, Silica gel (Merck KGaA, Darmstadt, Germany) was used for column chromatography. Purification by high-pressure liquid chromatography (HPLC) was performed using a Si gel column (LiChrospher Si 60, $10 \mu \mathrm{m}, 1 \mathrm{~cm}$ wide, $25 \mathrm{~cm}$ long, (VWR, Barcelona, Spain).

\subsection{Fungal Strain and Culture Conditions}

Trichoderma brevicompactum IBT 40841 (=IBT40841) (IBT Culture Collection, Department of Biotechnology, Technical University of Denmarck, Kongens Lyngby, Denmark) and tri5-overexpressing transformant Tb41tri5 [5] were used throughout this study. This strain was maintained on potato dextrose agar medium (PDA) (Difco Becton Dickinson, Sparks, MD, USA).

Six micelial plugs (6 mm each) of Tb41tri5 transformant strain were used to inoculate 0.5-L flasks containing $250 \mathrm{~mL}$ of potato dextrose broth (PDB) (Difco Becton Dickinson). Each flask was cultured at $25^{\circ} \mathrm{C}$ and $250 \mathrm{rpm}$ in the dark for 14 days. Sixteen 0.5-L flasks were used for trichodermin (1) extraction.

The yeast Candida albicans MY1055 used as the target in antimicrobial assays was maintained on Sabouraud dextrose agar (SDA) (Difco Becton Dickinson).

\subsection{Microorganism Used in the Bioassays}

The following microorganisms were used in the antimicrobial bioassays: Methicillin-resistant Staphylococcus aureus MRSA 5393, Staphylococcus aureus EPI167, Acinetobacter baumannii MB5973, Escherichia coli MB2884 and MB5746, Pseudomonas aeruginosa MB5919, Candida albicans MY1055, and Bacillus subtilis MB964. 


\subsection{Chemical Procedures}

\subsubsection{Trichodermin (1) Extraction}

Four liters of fermentation broth were filtered through $200 \mu \mathrm{m}$ Nylon filters and saturated with $\mathrm{NaCl}$, and the aqueous phase was extracted with ethyl acetate (EtOAc). The EtOAc extract was washed three times with $\mathrm{H}_{2} \mathrm{O}$ and then dried over anhydrous $\mathrm{Na}_{2} \mathrm{SO}_{4}$. Evaporation of the solvent under reduced pressure afforded a dense oil that was separated by means of flash chromatography on silica gel, with a mixture of ethyl acetate/hexane (20\% in EtOAc). The fractions were collected and purified by HPLC rendering $815 \mathrm{mg}$ of pure trichodermin (1). Spectroscopic methods, specifically ${ }^{1} \mathrm{H}$ NMR and ${ }^{13} \mathrm{C}$ NMR, were then employed to identify the molecule. Spectroscopic data for compound 1 were identical to those described in the literature [18].

\subsubsection{Preparation of Compound 3}

An aqueous solution of hydrochloric acid $(\mathrm{HCl})(5 \mathrm{~mL}, 10 \% \mathrm{v} / \mathrm{v})$ was added to trichodermin (1) (20.0 mg, $0.068 \mathrm{mmol})$. The mixture was stirred overnight at room temperature, and when TLC analysis indicated completion of the reaction $(14 \mathrm{~h})$, a diluted solution of sodium hydroxide $(\mathrm{NaOH})(1 \mathrm{M}$, was added until $\mathrm{pH}=7$. The aqueous phase was extracted with ethyl acetate $(3 \times 20 \mathrm{~mL})$, dried over anhydrous sodium sulfate and filtered. Evaporation of the solvent gave a crude product that was purified by silica gel column chromatography (petroleum ether/EtOAc, 80:20), to yield compound 3.

(4R,12S)-12-Hydroxy-12-(hydroxymethyl)trichothec-9-en-4-yl acetate (3) [21] (10.3 mg, 49\%). White solid; IR (film) $v_{\max } 3461,2968,1734,1238 \mathrm{~cm}^{-1}$; ${ }^{1} \mathrm{H}-\mathrm{NMR}\left(\mathrm{CDCl}_{3}, 400 \mathrm{MHz}\right) \delta 5.50(1 \mathrm{H}, \mathrm{m}, \mathrm{H}-10), 5.12(1 \mathrm{H}$, $\mathrm{dd}, J=5.6 \mathrm{~Hz}, 10.0, \mathrm{H}-4), 4.15(1 \mathrm{H}, \mathrm{dd}, J=6.1,11.3 \mathrm{~Hz}, \mathrm{H}-2), 3.88\left(1 \mathrm{H}, \mathrm{dd}, J=26.6,7.3 \mathrm{~Hz}, \mathrm{H}-13^{\prime}\right), 3.88$ $\left(1 \mathrm{H}, \mathrm{dd}, J=7.3,1.8 \mathrm{~Hz}, \mathrm{H}-13^{\prime \prime}\right), 3.75(1 \mathrm{H}, \mathrm{d}, J=5.2 \mathrm{~Hz}, \mathrm{H}-11), 2.57$ (1H, dt, J = 5.8, 11.8, H-3), $2.14(1 \mathrm{H}, \mathrm{t}$, OH-13), 2.05 (3H, s, H-2' ), 1.96 (3H, m, H-3, H-8), 1.71 (1H, dd, H-7'), 1.71 (3H, s, H-16), 1.27 (1H, m, H-7' $), 1.16$ (3H, s, H-14), 0.76 (3H, s, H-15); ${ }^{13} \mathrm{C} \mathrm{NMR}\left(\mathrm{CDCl}_{3}, 100 \mathrm{MHz}\right) \delta 170.2\left(\mathrm{C}-1^{\prime}\right), 141.0(\mathrm{C}-9)$, 117.3 (C-10), 90.4 (C-12), 77.7 (C-11), 73.0 (C-4), 64.6 (C-13), 63.1 (C-2), 58.0 (C-5), 43.6 (C-6), 38.7 (C-3), 27.8 (C-8), 25.3 (C-7), 23.3 (C-16), 21.0 (C-2'), 13.6 (C-15), 10.8 (C-14); HRMS(ESI $\left.{ }^{+}\right):$m/z 311.1837 [M + $\mathrm{H}^{+}$(calcd for $\mathrm{C}_{17} \mathrm{H}_{27} \mathrm{O}_{5}, 311.1858$ ).

\subsubsection{General Procedure for the Preparation of Compounds 4-5 [21]}

On a stirring solution of trichodermin (1) $(74 \mathrm{mg}, 0.25 \mathrm{mmol})$ in dry chloroform $\left(\mathrm{CHCl}_{3}, 6 \mathrm{~mL}\right)$, m-chloroperbenzoic acid (mCPBA) $(123 \mathrm{mg}, 70 \%, 0.5 \mathrm{mmol})$ was added at room temperature, and the reaction was monitored by TLC. After $6 \mathrm{~h}, 2 \mathrm{~mL}$ of a saturated solution of sodium hydrogen carbonate $\left(\mathrm{NaHCO}_{3}\right)$ was added to the reaction mixture and was then followed by the addition of sodium sulphite $\left(\mathrm{NaSO}_{3}\right)$. Distilled water $(5 \mathrm{~mL})$ was added, and the aqueous phase was extracted with $\mathrm{CHCl}_{3}$. The organic layer was dried over anhydrous $\mathrm{Na}_{2} \mathrm{SO}_{4}$, filtered, and the solvent was evaporated under reduced pressure. Column chromatography of the crude reaction mixture on silica gel, eluted with a gradient mixture of petroleum ether-EtOAc, produced a mixture of compounds 4 and 5 . Further purification with normal phase HPLC with petroleum ether/EtOAc (80:20) as mobile phase yielded pure compounds 4 and 5.

(4R,9S,10R)-9,10-Epoxy-12,13-epoxytrichothec-9-en-4-yl acetate (4). (5.6 mg, 7.2\%) Colourless oil; $[\alpha]_{\mathrm{D}}{ }^{20}$ $-12.9^{\circ}$ ( c 0.09, $\mathrm{CHCl}_{3}$ ); IR (film) $v_{\max } 2959,1736,1244,1219,1089 \mathrm{~cm}^{-1} ;{ }^{1} \mathrm{H}-\mathrm{NMR}\left(\mathrm{CDCl}_{3}, 400 \mathrm{MHz}\right)$ $\delta 5.55(1 \mathrm{H}, \mathrm{dd}, J=3.6,7.8 \mathrm{~Hz}, \mathrm{H}-4), 3.84(1 \mathrm{H}, \mathrm{d}, J=5.1 \mathrm{~Hz}, \mathrm{H}-2), 3.78(1 \mathrm{H}, \mathrm{br} . \mathrm{s}, \mathrm{H}-11), 3.11(1 \mathrm{H}, \mathrm{d}$, $J=4.0 \mathrm{~Hz}, \mathrm{H}-13), 2.93(1 \mathrm{H}, \mathrm{d}, J=1.8 \mathrm{~Hz}, \mathrm{H}-10), 2.79(1 \mathrm{H}, \mathrm{d}, J=4.0 \mathrm{~Hz}, \mathrm{H}-13), 2.50(1 \mathrm{H}, \mathrm{dd}, J=7.8$, $15.5 \mathrm{~Hz}, \mathrm{H}-3), 2.05$ (3H, s, H-2'), 2.00 (2H, m, H-3, H-7), 1.76 (2H, m, H-7,H-8), 1.33 (3H, s, H-16), 1.20 $(1 \mathrm{H}, \mathrm{m}, \mathrm{H}-8), 1.05$ (3H, s, H-15), $0.64(3 \mathrm{H}, \mathrm{s}, \mathrm{H}-14) ;{ }^{13} \mathrm{C}-\mathrm{NMR}\left(\mathrm{CDCl}_{3}, 100 \mathrm{MHz}\right) \delta 170.8\left(\mathrm{C}-1^{\prime}\right), 79.2$ (C-2), 74.7 (C-4), 70.2 (C-11), 65.0 (C-12), 61.5 (C-10), 57.3 (C-9), 49.5 (C-5), 47.8 (C-13), 40.3 (C-6), 36.3 (C-3), 25.8 (C-7), 24.2 (C-16), 24.2 (C-8), 21.1 (C-2'), 16.2 (C-15), 5.5 (C-14); HRMS (APGC $\left.{ }^{+}\right):$m/z 309.1706 $[\mathrm{M}+\mathrm{H}]^{+}$(calcd for $\left.\mathrm{C}_{17} \mathrm{H}_{25} \mathrm{O}_{5}, 309.1702\right)$; 
(4R,9R,10S)-9,10-Epoxy-12,13-epoxytrichothec-9-en-4-yl acetate (5). (63.4 mg, 82.3\%). Colourless oil; $[\alpha]_{\mathrm{D}}^{20}$ $-1.5^{\circ}$ ( c 0.65, $\mathrm{CHCl}_{3}$ ); IR (film) $v_{\max } 2971,1732,1245,1220,1093 \mathrm{~cm}^{-1} ;{ }^{1} \mathrm{H}-\mathrm{NMR}\left(\mathrm{CDCl}_{3}, 400 \mathrm{MHz}\right) \delta$ $5.55(1 \mathrm{H}, \mathrm{dd}, J=3.7,7.9 \mathrm{~Hz}, \mathrm{H}-4), 3.89(1 \mathrm{H}, \mathrm{d}, J=5.2 \mathrm{~Hz}, \mathrm{H}-2), 3.60(1 \mathrm{H}, \mathrm{dd}, J=2.2,5.6 \mathrm{~Hz}, \mathrm{H}-11), 3.15$ $(1 \mathrm{H}, \mathrm{d}, J=4.0 \mathrm{~Hz}, \mathrm{H}-13), 3.05(1 \mathrm{H}, \mathrm{d}, J=5.6 \mathrm{~Hz}, \mathrm{H}-10), 2.75(1 \mathrm{H}, \mathrm{d}, J=4.0 \mathrm{~Hz}, \mathrm{H}-13), 2.48(1 \mathrm{H}, \mathrm{dd}$, $J=7.9,15.4 \mathrm{~Hz}, \mathrm{H}-3), 2.06\left(3 \mathrm{H}, \mathrm{s}, \mathrm{H}-2^{\prime}\right), 1.98(1 \mathrm{H}, \mathrm{m}, \mathrm{H}-3), 1.88(1 \mathrm{H}, \mathrm{m}, \mathrm{H}-7), 1.70(2 \mathrm{H}, \mathrm{m}, \mathrm{H}-7, \mathrm{H}-8)$,

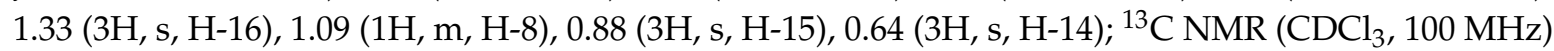
$\delta 170.9\left(\mathrm{C}-1^{\prime}\right), 78.8$ (C-2), 74.8 (C-4), 70.3 (C-11), 64.9 (C-12), 57.2 (C-10), 57.2 (C-9), 48.6 (C-5), 47.7 (C-13), 40.1 (C-6), 36.4 (C-3), 26.5 (C-7), 22.4 (C-16), 21.4 (C-8), 21.1 (C-2'), 16.8 (C-15), 5.7 (C-14); HRMS $\left(\mathrm{APGC}^{+}\right)$: $m / z 309.1706[\mathrm{M}+\mathrm{H}]^{+}$(calcd for $\left.\mathrm{C}_{17} \mathrm{H}_{25} \mathrm{O}_{5}, 309.1702\right)$.

\subsubsection{Preparation of Trichodermol (2)}

A methanolic solution of sodium hydroxide $(\mathrm{NaOH})(2 \mathrm{M}, 6 \mathrm{~mL})$ was added to trichodermin (1) (50 mg, $0.171 \mathrm{mmol}$ ), and the mixture was stirred at room temperature. After $45 \mathrm{~min}$, an aqueous solution of hydrochloric acid $(\mathrm{HCl}) 1 \mathrm{~N}$ was added dropwise until reaching $\mathrm{pH}=7$. The methanol was evaporated under reduced pressure, and the aqueous suspension was extracted with EtOAc. The organic layer was dried over anhydrous $\mathrm{Na}_{2} \mathrm{SO}_{4}$, filtered, and the solvent was evaporated under reduced pressure. Column chromatography of the crude reaction mixture on silica gel, eluted with a mixture of petroleum ether-EtOAc (50:50), yielded white crystals (42.5 mg, 99\%). Spectroscopic methods, specifically ${ }^{1} \mathrm{H}-\mathrm{NMR}$ and ${ }^{13} \mathrm{C}-\mathrm{NMR}$, were then employed to identify the molecule. Spectroscopic data for the compound were identical to those described in the literature for trichodermol 2 [27].

\subsubsection{Preparation of Compound 6}

On a stirring solution of trichodermol (2) $(20 \mathrm{mg}, 0.08 \mathrm{mmol})$ in dry dichloromethane $\left(\mathrm{CH}_{2} \mathrm{Cl}_{2}\right.$, $1 \mathrm{~mL}), m$-chloroperbenzoic acid (mCPBA) $(39.4 \mathrm{mg}, 70 \%, 0.16 \mathrm{mmol}$ ) was added at room temperature, and the reaction was monitored by TLC. After $6 \mathrm{~h}, 1 \mathrm{~mL}$ of a saturated solution of sodium hydrogen carbonate $\left(\mathrm{NaHCO}_{3}\right)$ was added to the reaction mixture, followed by sodium sulfite $\left(\mathrm{NaSO}_{3}\right)$. Distilled water $(5 \mathrm{~mL})$ was added, and the aqueous phase was extracted with $\mathrm{CH}_{2} \mathrm{Cl}_{2}$. The organic layer was dried over anhydrous $\mathrm{Na}_{2} \mathrm{SO}_{4}$, filtered, and the solvent was evaporated under reduced pressure. Column chromatography of the crude reaction mixture on silica gel, eluted with a gradient mixture of petroleum ether-EtOAc, yielded pure compound 6.

(4R,9R,10S)-9,10-Epoxy-12,13-epoxytrichothec-9-en-4-ol (6). (63.4 mg, 82.3\%). White solid; $[\alpha]_{\mathrm{D}}{ }^{20}-17.8^{\circ}$ (c 0.17, $\mathrm{CHCl}_{3}$ ); IR (film) $v_{\max } 3508,2964,2935,1086,746 \mathrm{~cm}^{-1},{ }^{1} \mathrm{H}-\mathrm{NMR}\left(\mathrm{CDCl}_{3}, 400 \mathrm{MHz}\right) \delta 4.29(1 \mathrm{H}$, $\mathrm{dd}, J=3.2,7.6 \mathrm{~Hz}, \mathrm{H}-4), 3.90(1 \mathrm{H}, \mathrm{d}, J=5.2 \mathrm{~Hz}, \mathrm{H}-2), 3.51(1 \mathrm{H}, \mathrm{dd}, J=2.3,5.6 \mathrm{~Hz}, \mathrm{H}-11), 3.13(1 \mathrm{H}, \mathrm{d}$, $J=3.8 \mathrm{~Hz}, \mathrm{H}-13), 3.03(1 \mathrm{H}, \mathrm{d}, J=5.6 \mathrm{~Hz}, \mathrm{H}-10), 2.74(1 \mathrm{H}, \mathrm{d}, J=3.8 \mathrm{~Hz}, \mathrm{H}-13), 2.56(1 \mathrm{H}, \mathrm{dd}, J=7.6$, $15.8 \mathrm{~Hz}, \mathrm{H}-3), 1.90$ (2H, m, H-3, H-7), 1.71 (2H, m, H-7,H-8), 1.32 (3H, s, H-16), 1.12 (1H, m, H-8), 0.81 (3H, s, H-15), 0.73 (3H, s, H-14).; ${ }^{13} \mathrm{C}-\mathrm{NMR}\left(\mathrm{CDCl}_{3}, 100 \mathrm{MHz}\right) \delta 78.38(\mathrm{C}-2), 73.98(\mathrm{C}-4), 70.05$ (C-11), 65.17 (C-12), 57.25 (C-10), 57.18 (C-9), 48.82 (C-5), 47.42 (C-13), 39.96 (C-3), 39.49 (C-6), 26.60 (C-7), 22.43 (C-16), 21.35 (C-8), 16.62 (C-15), 6.23 (C-14); HRMS (ESI $\left.{ }^{+}\right): m / z 267.1591[\mathrm{M}+\mathrm{H}]^{+}\left(\right.$calcd for $\mathrm{C}_{15} \mathrm{H}_{23} \mathrm{O}_{4}$, 267.1596).

\subsubsection{General Procedure for the Preparation of Trichodermol (2) C-4 derivatives (7-15)}

A solution of trichodermol (2) in dry $\mathrm{CH}_{2} \mathrm{Cl}_{2}$ was prepared in a Schlenk flask under an inert argon atmosphere. Dry pyridine $(\mathrm{d}=0.982 \mathrm{~g} / \mathrm{mL})$ was added, followed by the dropwise addition of acyl halide. The suspension was stirred at room temperature and monitored by TLC. When the reaction was completed, the crude mixture was supported on silica gel, and the products were separated by column chromatography and eluted with a gradient mixture of petroleum ether-EtOAc. Each product (7-15) was purified by HPLC. See supporting information, S2, for more details and yields.

(4R)-12,13-Epoxytrichothec-9-en-4-yl propionate (7). Colourless oil; $[\alpha]_{\mathrm{D}}^{20}-7.6^{\circ}$ (c 0.25, $\left.\mathrm{CHCl}_{3}\right)$; IR (film) $v_{\max } 3392,2979,1731,1192 \mathrm{~cm}^{-1} ;{ }^{1} \mathrm{H}-\mathrm{NMR}\left(\mathrm{CDCl}_{3}, 400 \mathrm{MHz}\right) \delta 5.56(1 \mathrm{H}, \mathrm{dd}, J=3.8,7.9 \mathrm{~Hz}, \mathrm{H}-4), 5.39$ 
(1H, m, H-10), $3.80(1 \mathrm{H}, \mathrm{d}, J=5.3 \mathrm{~Hz}, \mathrm{H}-2), 3.59(1 \mathrm{H}, \mathrm{d}, J=5.6 \mathrm{~Hz}, \mathrm{H}-11), 3.10(1 \mathrm{H}, \mathrm{d}, J=4.1 \mathrm{~Hz}, \mathrm{H}-13)$, $2.81(1 \mathrm{H}, \mathrm{d}, J=4.1 \mathrm{~Hz}, \mathrm{H}-13), 2.52(1 \mathrm{H}, \mathrm{dd}, J=7.9,15.5 \mathrm{~Hz}, \mathrm{H}-3), 2.35\left(2 \mathrm{H}, \mathrm{q}, J=7.6 \mathrm{~Hz}, \mathrm{H}-2^{\prime}\right), 1.94(4 \mathrm{H}$, m, H-3, H-7, H-8), 1.70 (3H, s, H-16), 1.39 (1H, m, H-7), 1.14 (3H, t, J = 7.6 Hz, H-3'), 0.92 (3H, s, H-15), 0.69 (3H, s, H-14).; ${ }^{13} \mathrm{C}-\mathrm{NMR}\left(\mathrm{CDCl}_{3}, 100 \mathrm{MHz}\right) \delta 174.3$ (C-1'), 140.2 (C-9), 118.6 (C-10), 79.1 (C-2), 74.8 (C-4), 70.5 (C-11), 65.5 (C-12), 48.9 (C-5), 47.8 (C-13), 40.4 (C-6), 36.7 (C-3), 27.9 (C-8), 27.7 (C-2), 24.4 (C-7), 23.2 (C-16), 15.9 (C-15), 9.1 (C-3'), 5.8 (C-14); HRMS (APGC $\left.{ }^{+}\right): m / z 307.1917[\mathrm{M}+\mathrm{H}]^{+}$(calcd for $\left.\mathrm{C}_{18} \mathrm{H}_{27} \mathrm{O}_{4}, 307.1909\right)$.

(4R)-12,13-Epoxytrichothec-9-en-4-yl butyrate (8). Colourless oil; $[\alpha]_{\mathrm{D}}{ }^{20}-4.6^{\circ}\left(\mathrm{c} 0.06, \mathrm{CHCl}_{3}\right)$; IR (film) $v_{\max } 2961,1729,1176,1078 \mathrm{~cm}^{-1} ;{ }^{1} \mathrm{H}-\mathrm{NMR}\left(\mathrm{CDCl}_{3}, 400 \mathrm{MHz}\right) \delta 5.56(1 \mathrm{H}, \mathrm{dd}, J=4.0,8.0 \mathrm{~Hz}, \mathrm{H}-4), 5.39$ $(1 \mathrm{H}, \mathrm{m}, \mathrm{H}-10), 3.81(1 \mathrm{H}, \mathrm{d}, J=5.2 \mathrm{~Hz}, \mathrm{H}-2), 3.60(1 \mathrm{H}, \mathrm{d}, J=5.6 \mathrm{~Hz}, \mathrm{H}-11), 3.11(1 \mathrm{H}, \mathrm{d}, J=4.0 \mathrm{~Hz}, \mathrm{H}-13)$, $2.81(1 \mathrm{H}, \mathrm{d}, J=4.0 \mathrm{~Hz}, \mathrm{H}-13), 2.52(1 \mathrm{H}, \mathrm{dd}, J=7.6,15.2 \mathrm{~Hz}, \mathrm{H}-3), 2.31\left(2 \mathrm{H}, \mathrm{t}, J=7.2 \mathrm{~Hz}, \mathrm{H}-2^{\prime}\right), 1.92$ $(4 \mathrm{H}, \mathrm{m}, \mathrm{H}-3, \mathrm{H}-7, \mathrm{H}-8), 1.70$ (3H, s, H-16), 1.65 (2H, td, J = 7.6 Hz, H-3'), 1.40 (1H, m, H-7), 0.94 (3H, $\left.\mathrm{t}, J=7.2 \mathrm{~Hz}, \mathrm{H}-4^{\prime}\right), 0.92(3 \mathrm{H}, \mathrm{s}, \mathrm{H}-15), 0.69(3 \mathrm{H}, \mathrm{s}, \mathrm{H}-14) . ;{ }^{13} \mathrm{C}-\mathrm{NMR}\left(\mathrm{CDCl}_{3}, 100 \mathrm{MHz}\right) \delta 173.5\left(\mathrm{C}-1^{\prime}\right)$, 140.2 (C-9), 118.6 (C-10), 79.1 (C-2), 74.8 (C-4), 70.5 (C-11), 65.5 (C-12), 48.9 (C-5), 47.8 (C-13), 40.4 (C-6), 36.7 (C-3), 36.3 (C-2'), 28.0 (C-8), 24.4 (C-7), 23.2 (C-16), 18.4 (C-3'), 16.0 (C-15), 13.6 (C-4'), 5.8 (C-14); HRMS $\left(\right.$ APGC $\left.^{+}\right): m / z 321.2077\left[\mathrm{M}+\mathrm{H}^{+}\left(\right.\right.$calcd for $\left.\mathrm{C}_{19} \mathrm{H}_{29} \mathrm{O}_{4}, 321.2066\right)$.

(4R)-12,13-Epoxytrichothec-9-en-4-yl pentanoate (9) [21]. Colourless oil; $[\alpha]_{\mathrm{D}}{ }^{20}-12.5^{\circ}\left(\right.$ c $\left.0.22, \mathrm{CHCl}_{3}\right)$; IR (film) $v_{\max } 2959,1731,1172,1079 \mathrm{~cm}^{-1} ;{ }^{1} \mathrm{H}-\mathrm{NMR}\left(\mathrm{CDCl}_{3}, 400 \mathrm{MHz}\right) \delta 5.55(1 \mathrm{H}, \mathrm{dd}, J=3.6,7.8 \mathrm{~Hz}, \mathrm{H}-4)$, $5.38(1 \mathrm{H}, \mathrm{m}, \mathrm{H}-10), 3.80(1 \mathrm{H}, \mathrm{d}, J=5.2 \mathrm{~Hz}, \mathrm{H}-2), 3.59(1 \mathrm{H}, \mathrm{d}, J=5.2 \mathrm{~Hz}, \mathrm{H}-11), 3.10(1 \mathrm{H}, \mathrm{d}, J=4.0 \mathrm{~Hz}$, $\mathrm{H}-13), 2.80(1 \mathrm{H}, \mathrm{d}, J=4.0 \mathrm{~Hz}, \mathrm{H}-13), 2.51(1 \mathrm{H}, \mathrm{dd}, J=7.8,15.4 \mathrm{~Hz}, \mathrm{H}-3), 2.32\left(2 \mathrm{H}, \mathrm{td}, J=7.4 \mathrm{~Hz}, \mathrm{H}-2^{\prime}\right)$, $1.90(4 \mathrm{H}, \mathrm{m}, \mathrm{H}-3, \mathrm{H}-7, \mathrm{H}-8), 1.69$ (3H, s, H-16), $1.59\left(2 \mathrm{H}, \mathrm{m}, J=7.6 \mathrm{~Hz}, \mathrm{H}-3^{\prime}\right), 1.31$ (3H, m, H-7, H-4' $)$, $0.92(3 \mathrm{H}, \mathrm{s}, \mathrm{H}-15), 0.89\left(3 \mathrm{H}, \mathrm{t}, J=7.4 \mathrm{~Hz}, \mathrm{H}-5^{\prime}\right), 0.69(3 \mathrm{H}, \mathrm{s}, \mathrm{H}-14) ;{ }^{13} \mathrm{C}-\mathrm{NMR}\left(\mathrm{CDCl}_{3}, 100 \mathrm{MHz}\right) \delta 173.7$ (C-1'), 140.1 (C-9), 118.6 (C-10), 79.1 (C-2), 74.8 (C-4), 70.4 (C-11), 65.5 (C-12), 48.9 (C-5), 47.8 (C-13), 40.4 (C-6), 36.7 (C-3), 34.1 (C-2'), 27.9 (C-8), 26.9 (C-3'), 24.4 (C-7), 23.2 (C-16), 22.2 (C-4'), 15.9 (C-15), 13.6 (C-5'), $5.8(\mathrm{C}-14)$; HRMS (APGC ${ }^{+}$): $\mathrm{m} / \mathrm{z} 335.2237[\mathrm{M}+\mathrm{H}]^{+}$(calcd for $\mathrm{C}_{20} \mathrm{H}_{31} \mathrm{O}_{4}, 335.2222$ ).

(4R)-12,13-Epoxytrichothec-9-en-4-yl hexanoate (10). Colourless oil; $[\alpha]_{\mathrm{D}}^{20}-14.5^{\circ}\left(c 0.25, \mathrm{CHCl}_{3}\right)$; IR (film) $v_{\max } 2957,1732,1171,1080 \mathrm{~cm}^{-1} ;{ }^{1} \mathrm{H}-\mathrm{NMR}\left(\mathrm{CDCl}_{3}, 400 \mathrm{MHz}\right) \delta 5.55(1 \mathrm{H}, \mathrm{dd}, J=3.6,7.8 \mathrm{~Hz}, \mathrm{H}-4)$, $5.38(1 \mathrm{H}, \mathrm{m}, \mathrm{H}-10), 3.80(1 \mathrm{H}, \mathrm{d}, J=5.2 \mathrm{~Hz}, \mathrm{H}-2), 3.58(1 \mathrm{H}, \mathrm{d}, J=5.5 \mathrm{~Hz}, \mathrm{H}-11), 3.10(1 \mathrm{H}, \mathrm{d}, J=4.0 \mathrm{~Hz}$, $\mathrm{H}-13), 2.80(1 \mathrm{H}, \mathrm{d}, J=4.0 \mathrm{~Hz}, \mathrm{H}-13), 2.51(1 \mathrm{H}, \mathrm{dd}, J=7.8,15.4 \mathrm{~Hz}, \mathrm{H}-3), 2.31\left(2 \mathrm{H}, \mathrm{td}, J=7.4 \mathrm{~Hz}, \mathrm{H}-2^{\prime}\right)$, $1.92(4 \mathrm{H}, \mathrm{m}, \mathrm{H}-3, \mathrm{H}-7, \mathrm{H}-8), 1.69(3 \mathrm{H}, \mathrm{s}, \mathrm{H}-16), 1.61\left(2 \mathrm{H}, \mathrm{m}, \mathrm{H}-3^{\prime}\right), 1.38(1 \mathrm{H}, \mathrm{m}, \mathrm{H}-7), 1.28\left(4 \mathrm{H}, \mathrm{m}, \mathrm{H}-4^{\prime}\right.$, $\left.\mathrm{H}-5^{\prime}\right), 0.92(3 \mathrm{H}, \mathrm{s}, \mathrm{H}-15), 0.87\left(3 \mathrm{H}, \mathrm{t}, J=7.2 \mathrm{~Hz}, \mathrm{H}-6^{\prime}\right), 0.69(3 \mathrm{H}, \mathrm{s}, \mathrm{H}-14) ;{ }^{13} \mathrm{C}-\mathrm{NMR}\left(\mathrm{CDCl}_{3}, 100 \mathrm{MHz}\right)$ $\delta 173.7$ (C-1'), 140.1 (C-9), 118.5 (C-10), 79.1 (C-2), 74.8 (C-4), 70.5 (C-11), 65.5 (C-12), 48.9 (C-5), 47.8 (C-13), 40.4 (C-6), 36.6 (C-3), 34.3 (C-2'), 31.2 (C-4'),27.9 (C-8), 24.5 (C-3'), 24.4 (C-7), 23.2 (C-16), 22.2 $\left(\mathrm{C}-5^{\prime}\right), 15.9(\mathrm{C}-15), 13.8\left(\mathrm{C}-6^{\prime}\right), 5.8(\mathrm{C}-14)$; HRMS $\left(\right.$ APGC $\left.^{+}\right): \mathrm{m} / z 349.2390[\mathrm{M}+\mathrm{H}]^{+}\left(\right.$calcd for $\mathrm{C}_{21} \mathrm{H}_{33} \mathrm{O}_{4}$, 349.2379).

(4R)-12,13-Epoxytrichothec-9-en-4-yl heptanoate (11). Colourless oil; $[\alpha]_{\mathrm{D}}{ }^{20}-11.7^{\circ}\left(\mathrm{c} 0.25, \mathrm{CHCl}_{3}\right)$; IR (film) $v_{\max } 2931,1731,1168,1081 \mathrm{~cm}^{-1} ;{ }^{1} \mathrm{H}-\mathrm{NMR}\left(\mathrm{CDCl}_{3}, 400 \mathrm{MHz}\right) \delta 5.55(1 \mathrm{H}, \mathrm{dd}, J=3.8,7.9 \mathrm{~Hz}, \mathrm{H}-4)$, $5.38(1 \mathrm{H}, \mathrm{m}, \mathrm{H}-10), 3.80(1 \mathrm{H}, \mathrm{d}, J=5.3 \mathrm{~Hz}, \mathrm{H}-2), 3.59(1 \mathrm{H}, \mathrm{d}, J=5.3 \mathrm{~Hz}, \mathrm{H}-11), 3.10(1 \mathrm{H}, \mathrm{d}, J=4.1 \mathrm{~Hz}$, $\mathrm{H}-13), 2.80(1 \mathrm{H}, \mathrm{d}, J=4.1 \mathrm{~Hz}, \mathrm{H}-13), 2.51(1 \mathrm{H}, \mathrm{dd}, J=7.9,15.5 \mathrm{~Hz}, \mathrm{H}-3), 2.31\left(2 \mathrm{H}, \mathrm{t}, J=7.3 \mathrm{~Hz}, \mathrm{H}-2^{\prime}\right)$, 1.95 (4H, m, H-3, H-7, H-8), 1.69 (3H, s, H-16), 1.60 (2H, m, H-3'), 1.39 (1H, m, H-7), 1.27 (6H, m, H-4', H-5', $\left.\mathrm{H}-6^{\prime}\right), 0.92$ (3H, s, H-15), 0.86 (3H, m, H-7'), 0.69 (3H, s, H-14).; ${ }^{13} \mathrm{C}-\mathrm{NMR}\left(\mathrm{CDCl}_{3}, 100 \mathrm{MHz}\right) \delta$ 173.8 (C-1'), 140.2 (C-9), 118.5 (C-10), 79.1 (C-2), 74.8 (C-4), 70.5 (C-11), 65.5 (C-12), 48.9 (C-5), 47.8 (C-13), 40.4 (C-6), 36.7 (C-3), 34.4 (C-2'), $31.4\left(\mathrm{C}-5^{\prime}\right), 28.7$ (4'), 27.9 (C-8), 24.8 (C-3'), 24.4 (C-7), 23.2 (C-16), $22.4\left(\mathrm{C}-6^{\prime}\right), 15.9$ (C-15), $13.9\left(\right.$ C-7' $\left.^{\prime}\right), 5.8(\mathrm{C}-14)$; HRMS $\left(\right.$ APGC $\left.^{+}\right): \mathrm{m} / \mathrm{z} 363.2537[\mathrm{M}+\mathrm{H}]^{+}$(calcd for $\left.\mathrm{C}_{22} \mathrm{H}_{35} \mathrm{O}_{4}, 363.2535\right)$.

(4R)-12,13-Epoxytrichothec-9-en-4-yl acrylate (12) [21]. Colourless oil; $[\alpha]_{\mathrm{D}}{ }^{20}-14.9^{\circ}\left(c 0.13, \mathrm{CHCl}_{3}\right) ; \mathrm{IR}$ (film) $v_{\max } 2972,1717,1192,1079 \mathrm{~cm}^{-1} ;{ }^{1} \mathrm{H}-\mathrm{NMR}\left(\mathrm{CDCl}_{3}, 400 \mathrm{MHz}\right) \delta 6.42(1 \mathrm{H}, \mathrm{dd}, J=1.5,17.3 \mathrm{~Hz}$, H-3'), $6.14\left(1 \mathrm{H}, \mathrm{dd}, J=10.4,17.3 \mathrm{~Hz}, \mathrm{H}-2^{\prime}\right), 5.83\left(1 \mathrm{H}, \mathrm{dd}, J=1.5,10.4 \mathrm{~Hz}, \mathrm{H}-3^{\prime}\right), 5.63(1 \mathrm{H}, \mathrm{dd}, J=3.5$, 
$7.9 \mathrm{~Hz}, \mathrm{H}-4), 5.40(1 \mathrm{H}, \mathrm{m}, \mathrm{H}-10), 3.83(1 \mathrm{H}, \mathrm{d}, J=5.3 \mathrm{~Hz}, \mathrm{H}-2), 3.62(1 \mathrm{H}, \mathrm{d}, J=5.6 \mathrm{~Hz}, \mathrm{H}-11), 3.12(1 \mathrm{H}, \mathrm{d}$, $J=4.1 \mathrm{~Hz}, \mathrm{H}-13), 2.82(1 \mathrm{H}, \mathrm{d}, J=4.1 \mathrm{~Hz}, \mathrm{H}-13), 2.56(1 \mathrm{H}, \mathrm{dd}, J=7.9,15.5 \mathrm{~Hz}, \mathrm{H}-3), 1.98(4 \mathrm{H}, \mathrm{m}, \mathrm{H}-3$, H-7, H-8), 1.71 (3H, s, H-16), 1.41 (1H, m, H-7), 0.94 (3H, s, H-15), 0.72 (3H, s, H-14).; ${ }^{13} \mathrm{C}_{-\mathrm{NMR}}\left(\mathrm{CDCl}_{3}\right.$, $100 \mathrm{MHz}) \delta 166.0\left(\mathrm{C}-1^{\prime}\right), 140.2(\mathrm{C}-9), 131.0\left(\mathrm{C}-3^{\prime}\right), 128.4\left(\mathrm{C}-2^{\prime}\right), 118.6$ (C-10), 79.1 (C-2), 75.3 (C-4), 70.5 (C-11), 65.5 (C-12), 49.2 (C-5), 47.8 (C-13), 40.4 (C-6), 36.6 (C-3), 28.0 (C-8), 24.4 (C-7), 23.2 (C-16), 16.0 (C-15), 5.8 (C-14); HRMS (APGC ${ }^{+}$): $\mathrm{m} / \mathrm{z} 305.1748[\mathrm{M}+\mathrm{H}]^{+}$(calcd for $\mathrm{C}_{18} \mathrm{H}_{25} \mathrm{O}_{4}, 305.1753$ ).

(4R)-12,13-Epoxytrichothec-9-en-4-yl (E)-but-2-enoate (13) [21]. Colourless oil; $[\alpha]_{\mathrm{D}}^{20}-17.8^{\circ}$ (c 0.18, $\left.\mathrm{CHCl}_{3}\right)$; IR (film) $v_{\max } 2968,1716,1180,1079 \mathrm{~cm}^{-1} ;{ }^{1} \mathrm{H}-\mathrm{NMR}\left(\mathrm{CDCl}_{3}, 400 \mathrm{MHz}\right) \delta 6.98(1 \mathrm{H}, \mathrm{dq}, J=7.0$, $\left.15.4 \mathrm{~Hz}, \mathrm{H}-3^{\prime}\right), 5.86\left(1 \mathrm{H}, \mathrm{dq}, J=1.8,15.4 \mathrm{~Hz}, \mathrm{H}-2^{\prime}\right), 5.60(1 \mathrm{H}, \mathrm{dd}, J=3.6,8 \mathrm{~Hz}, \mathrm{H}-4), 5.39(1 \mathrm{H}, \mathrm{m}, \mathrm{H}-10)$, $3.81(1 \mathrm{H}, \mathrm{d}, J=5.2 \mathrm{~Hz}, \mathrm{H}-2), 3.61(1 \mathrm{H}, \mathrm{d}, J=5.2 \mathrm{~Hz}, \mathrm{H}-11), 3.11(1 \mathrm{H}, \mathrm{d}, J=4.0 \mathrm{~Hz}, \mathrm{H}-13), 2.81(1 \mathrm{H}, \mathrm{d}$, $J=4.0 \mathrm{~Hz}, \mathrm{H}-13), 2.54(1 \mathrm{H}, \mathrm{dd}, J=7.6,15.2 \mathrm{~Hz}, \mathrm{H}-3), 1.97(4 \mathrm{H}, \mathrm{m}, \mathrm{H}-3, \mathrm{H}-7, \mathrm{H}-8), 1.86(3 \mathrm{H}, \mathrm{dd}, J=1.8$, $\left.7 \mathrm{~Hz}, \mathrm{H}-4^{\prime}\right), 1.70(3 \mathrm{H}, \mathrm{s}, \mathrm{H}-16), 1.40(1 \mathrm{H}, \mathrm{m}, \mathrm{H}-7), 0.93(3 \mathrm{H}, \mathrm{s}, \mathrm{H}-15), 0.70(3 \mathrm{H}, \mathrm{s}, \mathrm{H}-14) ;{ }^{13} \mathrm{C}-\mathrm{NMR}\left(\mathrm{CDCl}_{3}\right.$, $100 \mathrm{MHz}) \delta 166.2\left(\mathrm{C}-1^{\prime}\right), 145.1\left(\mathrm{C}-3^{\prime}\right), 140.2(\mathrm{C}-9), 122.7\left(\mathrm{C}-2^{\prime}\right), 118.6$ (C-10), 79.1 (C-2), 74.7 (C-4), 70.5 (C-11), 65.5 (C-12), 49.1 (C-5), 47.8 (C-13), 40.4 (C-6), 36.7 (C-3), 28.0 (C-8), 24.4 (C-7), 23.2 (C-16), 17.9 (C-4'), 16.0 (C-15), 5.8 (C-14); HRMS (APGC ${ }^{+}$): $\mathrm{m} / z 319.1912[\mathrm{M}+\mathrm{H}]^{+}$(calcd for $\mathrm{C}_{19} \mathrm{H}_{27} \mathrm{O}_{4}, 319.1909$ ).

(4R)-12,13-Epoxytrichothec-9-en-4-yl 3-methylbutanoate (14). Colourless oil; $[\alpha]_{\mathrm{D}}{ }^{20}-16.8^{\circ}\left(c\right.$ 0.21, $\left.\mathrm{CHCl}_{3}\right)$; IR (film) $v_{\max } 2960,1731,1189,1080 \mathrm{~cm}^{-1}$; ${ }^{1} \mathrm{H}-\mathrm{NMR}\left(\mathrm{CDCl}_{3}, 400 \mathrm{MHz}\right) \delta 5.55(1 \mathrm{H}, \mathrm{dd}, J=3.6,7.8 \mathrm{~Hz}$, H-4), $5.39(1 \mathrm{H}, \mathrm{m}, \mathrm{H}-10), 3.80(1 \mathrm{H}, \mathrm{d}, J=5.2 \mathrm{~Hz}, \mathrm{H}-2), 3.59(1 \mathrm{H}, \mathrm{d}, J=5.5 \mathrm{~Hz}, \mathrm{H}-11), 3.10(1 \mathrm{H}, \mathrm{d}$, $J=4.0 \mathrm{~Hz}, \mathrm{H}-13), 2.81(1 \mathrm{H}, \mathrm{d}, J=4.0 \mathrm{~Hz}, \mathrm{H}-13), 2.53(1 \mathrm{H}, \mathrm{dd}, J=7.9,15.5 \mathrm{~Hz}, \mathrm{H}-3), 2.21(2 \mathrm{H}, \mathrm{d}, J=6.9 \mathrm{~Hz}$, H-2'), 2.10 (1H, m, H-3'), 1.94 (4H, m, H-3, H-7, H-8), 1.70 (3H, s, H-16), 1.40 (1H, m, H-7), 0.95 (3H, s, $\left.\mathrm{H}-4^{\prime *}\right), 0.94\left(3 \mathrm{H}, \mathrm{s}, \mathrm{H}-5^{\prime *}\right), 0.92(3 \mathrm{H}, \mathrm{s}, \mathrm{H}-15), 0.70(3 \mathrm{H}, \mathrm{s}, \mathrm{H}-14) ;{ }^{13} \mathrm{C}-\mathrm{NMR}\left(\mathrm{CDCl}_{3}, 100 \mathrm{MHz}\right) \delta 173.0$ (C-1'), 140.1 (C-9), 118.6 (C-10), 79.1 (C-2), 74.8 (C-4), 70.5 (C-11), 65.5 (C-12), 48.8 (C-5), 47.8 (C-13), 43.4 (C-2'), 40.4 (C-6), 36.8 (C-3), 27.9 (C-8), 25.5 (C-3'), 24.4 (C-7), 23.2 (C-16), $22.4\left(\mathrm{C}-4^{\prime *}\right), 22.3\left(\mathrm{C}-5^{\prime *}\right), 15.9$ (C-15), 5.9 (C-14); HRMS (APGC ${ }^{+}$): $\mathrm{m} / z$ 335.2222 [M + H] $]^{+}$(calcd for $\mathrm{C}_{20} \mathrm{H}_{28} \mathrm{O}_{4}, 335.2222$ ).

(4R)-12,13-Epoxytrichothec-9-en-4-yl 2-(benzyloxy)acetate (15). Colourless oil; $[\alpha]_{\mathrm{D}}^{20}-11.8^{\circ}$ (c 0.27 , $\left.\mathrm{CHCl}_{3}\right)$; IR (film) $v_{\max } 3332,2970,1749,1731,1200,1125,1079 \mathrm{~cm}^{-1} ;{ }^{1} \mathrm{H}-\mathrm{NMR}\left(\mathrm{CDCl}_{3}, 400 \mathrm{MHz}\right) \delta$ $7.36\left(5 \mathrm{H}, \mathrm{m}, \mathrm{H}-5^{\prime}, \mathrm{H}-6^{\prime}, \mathrm{H}-7^{\prime}, \mathrm{H}-8^{\prime}, \mathrm{H}-9^{\prime}\right), 5.67$ (1H, dd, J = 3.6, 7.8 Hz, H-4), 5.40 (1H, m, H-10), 4.64 $\left(2 \mathrm{H}, \mathrm{s}, \mathrm{H}-3^{\prime}\right), 4.12\left(2 \mathrm{H}, \mathrm{s}, \mathrm{H}-2^{\prime}\right), 3.82(1 \mathrm{H}, \mathrm{d}, J=5.2 \mathrm{~Hz}, \mathrm{H}-2), 3.59(1 \mathrm{H}, \mathrm{d}, J=5.6 \mathrm{~Hz}, \mathrm{H}-11), 3.11(1 \mathrm{H}, \mathrm{d}$, $J=4.0 \mathrm{~Hz}, \mathrm{H}-13), 2.80(1 \mathrm{H}, \mathrm{d}, J=4.0 \mathrm{~Hz}, \mathrm{H}-13), 2.55(1 \mathrm{H}, \mathrm{dd}, J=7.8,15.4 \mathrm{~Hz}, \mathrm{H}-3), 1.96(4 \mathrm{H}, \mathrm{m}, \mathrm{H}-3$, H-7, H-8), 1.70 (3H, s, H-16), 1.40 (1H, m, H-7), 0.94 (3H, s, H-15), 0.70 (3H, s, H-14); ${ }^{13} \mathrm{C}-\mathrm{NMR}\left(\mathrm{CDCl}_{3}\right.$, $100 \mathrm{MHz}) \delta 170.3\left(\mathrm{C}-1^{\prime}\right), 140.2(\mathrm{C}-9), 137.0\left(\mathrm{C}-4^{\prime}\right), 128.4\left(\mathrm{C}-5^{\prime}, \mathrm{C}-9^{\prime}\right), 128.0\left(\mathrm{C}-6^{\prime}, \mathrm{C} 8^{\prime}\right), 127.9\left(\mathrm{C}-7^{\prime}\right), 118.5$ (C-10), 79.0 (C-2), 75.6 (C-4), 73.3 (C-3'), 70.5 (C-11), 67.0 (C-2'), 65.4 (C-12), 49.1 (C-5), 47.8 (C-13), 40.4 (C-6), 36.5 (C-3), 27.9 (C-8), 24.4 (C-7), 23.2 (C-16), 16.0 (C-15), 5.8 (C-14); HRMS (APGC ${ }^{+}$): m/z 399.2174 $[\mathrm{M}+\mathrm{H}]^{+}$(calcd for $\left.\mathrm{C}_{24} \mathrm{H}_{31} \mathrm{O}_{5}, 399.2171\right)$.

\subsubsection{Preparation of Compound 16}

A solution of trichodermol (2) $(10 \mathrm{mg}, 0.04 \mathrm{mmol})$ in dry $\mathrm{CH}_{2} \mathrm{Cl}_{2}(3 \mathrm{~mL})$ was prepared in a Schlenk flask. Dry pyridine $(100 \mu \mathrm{L}, \mathrm{d}=0.982 \mathrm{~g} / \mathrm{mL})$ was added, followed by propanoyl chloride $(100 \mu \mathrm{L}, 98 \%$, $\mathrm{d}=1.059,1.1 \mathrm{mmol})$. The suspension was stirred at room temperature overnight. The crude mixture was supported on silica gel, and the product was separated by column chromatography and eluted with a gradient mixture of petroleum ether-EtOAc. Further purification with normal phase HPLC with petroleum ether/EtOAc (80:20) as the mobile phase yielded pure compound $\mathbf{1 6 .}$

$(4 R, 12 S)-12-H y d r o x y-12-h y d r o x y m e t h y l t r i c h o t h e c-9-e n-4-y l$ propionate (16) Colourless oil; $[\alpha]_{\mathrm{D}}{ }^{20}+5.9^{\circ}(c$ $\left.0.33, \mathrm{CHCl}_{3}\right)$; IR (film) $v_{\max } 3479,2969,1732,1183 \mathrm{~cm}^{-1} ;{ }^{1} \mathrm{H}-\mathrm{NMR}\left(\mathrm{CDCl}_{3}, 400 \mathrm{MHz}\right) \delta 5.50(1 \mathrm{H}, \mathrm{m}$, H-10), $5.13(1 \mathrm{H}, \mathrm{dd}, J=4.0,8.0 \mathrm{~Hz}, \mathrm{H}-4), 4.15(1 \mathrm{H}, \mathrm{dd}, J=6.0,11.2 \mathrm{~Hz}, \mathrm{H}-2), 3.87(2 \mathrm{H}, \mathrm{m}, \mathrm{H}-13), 3.75$ $(1 \mathrm{H}, \mathrm{d}, J=5.2 \mathrm{~Hz}, \mathrm{H}-11), 2.57(1 \mathrm{H}, \mathrm{dt}, J=5.9,11.9 \mathrm{~Hz}, \mathrm{H}-3), 2.33\left(2 \mathrm{H}, \mathrm{q}, J=10.4 \mathrm{~Hz}, \mathrm{H}-2^{\prime}\right), 2.14(1 \mathrm{H}, \mathrm{t}$, OH-13), 1.93 (3H, m, H-3, H-8), $1.71(1 \mathrm{H}, \mathrm{m}, \mathrm{H}-7), 1.71(3 \mathrm{H}, \mathrm{s}, \mathrm{H}-16), 1.27$ (1H, m, H-7), 1.16 (3H, s, $\mathrm{H}-14), 1.14\left(3 \mathrm{H}, \mathrm{t}, J=7.6 \mathrm{~Hz}, \mathrm{H}-3^{\prime}\right), 0.75(3 \mathrm{H}, \mathrm{s}, \mathrm{H}-15) ;{ }^{13} \mathrm{C}-\mathrm{NMR}\left(\mathrm{CDCl}_{3}, 100 \mathrm{MHz}\right) \delta 173.5\left(\mathrm{C}-1^{\prime}\right), 141.0$ 
(C-9), 117.3 (C-10), 90.5 (C-12), 77.7 (C-11), 72.8 (C-4), 64.6 (C-13), 63.2 (C-2), 58.1 (C-5), 43.6 (C-6), 38.7

(C-3), 27.8 (C-8), $27.8\left(\mathrm{C}-2^{\prime}\right), 25.3$ (C-7), 23.3 (C-16), 13.7 (C-15), 10.8 (C-14), 9.1 (C-3'); HRMS (ESI $\left.{ }^{+}\right): m / z$ $347.1830[\mathrm{M}+\mathrm{Na}]^{+}$(calcd for $\mathrm{C}_{18} \mathrm{H}_{28} \mathrm{O}_{5} \mathrm{Na}, 347.1834$ ).

\subsection{Evaluation of Antimicrobial Activity}

\subsubsection{Antifungal Assay}

Sabouraud Dextrose Agar (SDA) plates were inoculated with C. albicans MY1055 and incubated for $24 \mathrm{~h}$ at $35^{\circ} \mathrm{C}$. The raised colonies were collected from the SDA plates and resuspended in modified RPMI-1640 medium, which was prepared with $20.8 \mathrm{~g}$ of RPMI medium (Sigma-Aldrich, Madrid, Spain), $13.4 \mathrm{~g}$ of YNB (Yeast Nitrogen Base), $80 \mathrm{~mL}$ of $1 \mathrm{M}$ HEPES, and $72 \mathrm{~mL}$ of $50 \%$ glucose. The volume was adjusted to $2 \mathrm{~L}$ with MilliQ water and filtered. The OD at $660 \mathrm{~nm}$ of the colony suspension was adjusted to 0.25 using RPMI-1640 modified medium as diluent and blank. This inoculum was then again diluted to 1:10 and kept on ice until it was used to inoculate the 96-well microtiter plates. For the assay, $90 \mu \mathrm{L} /$ well of diluted 1:10 inoculum was mixed with $1.6 \mu \mathrm{L} /$ well of compound solution in DMSO and $8.4 \mu \mathrm{L} /$ well of modified RPMI-1640 medium. Amphotericin B and penicillin G were used as positive and negative internal controls, respectively. After distribution to the test plates of the inoculum, samples, and controls, the absorbance at $\mathrm{T}_{0}$ (zero time) was measured at a $612 \mathrm{~nm} \mathrm{DO}$ with a Tecan Ultraevolution spectrophotometer. The plates were then incubated at $37^{\circ} \mathrm{C}$ for $20 \mathrm{~h}$. Following this incubation period, the plates were shaken on a Micromix-5 shaker (Marshall Scientific, Hampton, NH, USA), and the absorbance at $\mathrm{T}_{\mathrm{f}}$ (final time) was again measured at the same OD as initially. Percent growth inhibition (PGI) was then calculated.

Compounds 1-16 were serially diluted in DMSO with a dilution factor of 2 to provide 10 concentrations starting at $64 \mu \mathrm{g} / \mathrm{mL}$. MIC was defined as the lowest concentration of an antimicrobial or antifungal compound that inhibited $\geq 95 \%$ growth of a microorganism after overnight incubation. Data were analyzed using the Screener Genedata program (Genedata AG, Basel, Switzerland). In all the experiments performed in this work, the RZ 'factor obtained was between 0.85 and 0.95 .

\subsubsection{Antibacterial Test}

The bacterial strains (Methicillin-resistant Staphylococcus aureus MRSA MB5393, Acinetobacter baumannii MB5973, Escherichia coli MB2884 and MB5746, and Pseudomonas aeruginosa MB5919) were re-plated on Luria-Bertani agar plates (LBA, $40 \mathrm{~g} / \mathrm{L}$ ) and incubated at $37^{\circ} \mathrm{C}$ overnight to obtain isolated colonies. The individual colonies of each microorganism were inoculated with $25 \mathrm{~mL}$ of Luria-Bertani medium (LB, $25 \mathrm{~g} / \mathrm{L}$ ) in $250 \mathrm{~mL}$ Erlenmeyer flasks and incubated overnight at $37{ }^{\circ} \mathrm{C}$ with shaking at $220 \mathrm{rpm}$. The bacterial inocula were then diluted to obtain the corresponding equivalents for the assay of approximately $1.1 \times 10^{6} \mathrm{CFU} / \mathrm{mL}(\mathrm{MRSA})$ or $5-6 \times 10^{5} \mathrm{CFU} / \mathrm{mL}$ (A. baumannii, E. coli and $P$. aeruginosa). For the assay, $90 \mu \mathrm{L} /$ well of diluted inoculum were mixed with $1.6 \mu \mathrm{L} /$ well of each compound dissolved in DMSO and $8.4 \mu \mathrm{L} /$ well of LB medium. Kanamycin and amphotericin B (MRSA), rifampicin and amphotericin B (A. baumannii), novobiocin and amphotericin B (E. coli), and ciprofloxacin and amphotericin B (P. aeruginosa) were included as positive and negative internal controls respectively on each plate. The absorbance at $\mathrm{T}_{0}$ (zero time) was measured at $612 \mathrm{~nm}$ with a Tecan Ultra Evolution spectrophotometer and immediately thereafter, the plates were incubated at 37 ${ }^{\circ} \mathrm{C}$ for $20 \mathrm{~h}$. After this period, the assay plates were shaken using a Micromix- 5 agitator and once again the absorbance at $\mathrm{T}_{\mathrm{f}}$ (final time) was measured at an OD of $612 \mathrm{~nm}$. Percent growth inhibition was calculated and the MIC was defined in the same way as described for C. albicans. The data were also analyzed using the Screener Genedata program (Genedata AG, Switzerland). In all the experiments performed in this work, the RZ 'factor obtained was between 0.85 and 0.95 . Assays on agar plates were conducted to determine antimicrobial susceptibility against vancomycin resistant B. subtilis MB964 and $\beta$-lactam antibiotics. B. subtilis MB964 assay plates were prepared by adding $1 \mathrm{~mL}\left(1.5 \times 10^{8}\right.$ $\mathrm{CFU} / \mathrm{mL}$ ) of a suspension of $B$. subtilis spores directly to $1 \mathrm{~L}$ of yeast extract and nutrient agar medium 
(NAYE, nutrient agar $23 \mathrm{~g} / \mathrm{L}$, yeast extract $2 \mathrm{~g} / \mathrm{L}$ ) and pouring $30 \mathrm{~mL}$ of this mixture into each test plate. The compounds were serially diluted in $20 \%$ DMSO with a dilution factor of 2 to provide 10 compound concentrations starting at $64 \mu \mathrm{g} / \mathrm{mL}$. Ten microliters of each compound concentration were added to the agar plate containing the pathogenic microorganism. Activity was determined by measuring the size of the inhibition halos.

\subsubsection{MTT Cytotoxicity Assay}

The MTT tetrazole reduction rate is an indicator of the functional integrity of the mitochondria and, hence, of cellular viability. Day 1: Cells were seeded at their corresponding concentrations in 96-well plates and allowed to incubate for $24 \mathrm{~h}$. Day 2: The media was stripped from the plates, and then the previously prepared compounds were added in $100 \% \mathrm{DMSO}$, serial $\frac{1}{2}$ dilutions. Compounds were added in a 1:200 dilution ( $2 \mu \mathrm{L}$ of compound/600 $\mu \mathrm{L}$ of medium) using a BiomekFX TM multi-well automatic plate dispenser (Beckman Coulter). Of this mixture, $200 \mu \mathrm{L}$ were pipetted to three-cell plates, resulting in each compound tested in triplicate with a constant DMSO percentage of $10.5 \%$. We used MMS ( $2 \mathrm{mM}$ ) as a positive control and DMSO as negative control at the same concentration at which the compounds and controls had been dissolved. Day 3: Compounds were incubated with the cells for $24 \mathrm{~h}$. The MTT was then added to a final concentration of $0.5 \mathrm{mg} / \mathrm{mL}$ and allowed to incubate with the cells for $3 \mathrm{~h}$. The chromogenic formazan concentration generated by spectrophotometry at 570 $\mathrm{nm}$ was then determined in a Victor2 ${ }^{\mathrm{TM}}$ multi-well plate reader (PerkinElmer). Data were analyzed using the ScreenerTM (Genedata) program for the calculation of $\mathrm{IC}_{50}$ (dose causing $50 \%$ cell death), taking as treatment $100 \%$ cell death (positive control) with $1 \mathrm{mM} \mathrm{MMS}$, and as $0 \%$ cell death (negative control) $0.5 \%$ DMSO. The percentage of cell death for each concentration was calculated. Then, using the Levenberg-Marquardt algorithm to adjust the dose-response curve, the $\mathrm{IC}_{50}$ of each compound was calculated by interpolating the curve thus obtained.

\section{Conclusions}

The results presented in this paper point to trichodermin (1) as a molecule with great potential as a model in the development of new drugs. Our results show that, through simple modifications on the trichodermin skeleton (1), it is possible to modulate bioactivity and obtain derivatives that are of great interest in the research and development of new molecules with potential use as antimicrobial agents and/or cytotoxic cancer treatment drugs. The specificity observed in the biological activity of these trichothecenes should spark further study of their mechanisms of action through the use of other study models.

Supplementary Materials: The following are available online at http://www.mdpi.com/1420-3049/24/20/3811/s1: Part A: General conditions for the preparation of compounds 7-15. Part B: Antimicrobial and cytotoxic activities of compounds 1-16. 1H and 13C-NMR spectra for compounds 3-16.

Author Contributions: I.G.C. and F.V. conceived and directed this project. E.M. and S.G. designed and directed the molecular experiments of overexpression of the tri 5 gene. J.E.B. synthetized the trichodermin derivatives and wrote the paper. M.D.L.C., N.D.P., and B.C. performed the cytotoxic and antimicrobial experiments. R.H. and R.E.C. performed the preparation of the transformants of T. brevicompactum.

Funding: The MEDINA authors disclosed the receipt of financial support from Fundación MEDINA, a public-private partnership of Merck Sharp \& Dohme de España S.A./Universidad de Granada/Junta de Andalucía.

Acknowledgments: This research was supported by grants from the Spanish Government MINECO-FEDER (RTI2018-097356-B-C21) and the Regional Government of Castile and Leon (SA270P18). J.E.B. is grateful to ITAIPU Binacional (Paraguay) and CONACYT-Paraguay for his research fellowship. Use of NMR and mass spectrometry (QTOF) facilities at Servicio Centralizado de Ciencia y Tecnología (SCCYT) of the University of Cádiz is acknowledged.

Conflicts of Interest: The authors declare no conflict of interest. 


\section{References}

1. Lachance, H.; Wetzel, S.; Kumar, K.; Waldmann, H. Charting, navigating, and populating natural product chemical space for drug discovery. J. Med. Chem. 2012, 55, 5989-6001. [CrossRef] [PubMed]

2. Gerry, C.J.; Schreiber, S.L. Chemical probes and drug leads from advances in synthetic planning and methodology. Nat. Rev. Drug. Discov. 2018, 17, 333-352. [CrossRef] [PubMed]

3. Newman, D.J.; Cragg, G.M. Natural Products as Sources of New Drugs from 1981 to 2014. J. Nat. Prod. 2016, 79, 629-661. [CrossRef] [PubMed]

4. Firn, R. Nature's Chemicals. The Natural Products That Shaped Our World; Oxford University Press: Oxford, UK, 2010; Volume 106.

5. Tijerino, A.; Cardoza, R.E.; Moraga, J.; Malmierca, M.G.; Vicente, F.; Aleu, J.; Collado, I.G.; Gutiérrez, S.; Monte, E.; Hermosa, R. Overexpression of the trichodiene synthase gene tri5 increases trichodermin production and antimicrobial activity in Trichoderma brevicompactum. Fungal Genet. Biol. 2011, 48, 285-296. [CrossRef]

6. Dewick, P.M. Medicinal Natural Products: A Biosynthetic Approach; John Wiley \& Sons, Ltd.: West Sussex, NJ, USA, 2009; Volume 84.

7. Beremand, M.N.; Mc Cormick, S.P. Biosynthesis and regulation of trichothecene production by Fusarium species. In Handbook of Applied Mycology. Mycotoxins in Ecological Systems; Bhatnagar, D., Lilehoj, E.B., Arora, D.K., Eds.; Marcel Dekker, Inc.: New York, USA, 1992; Volume 5, pp. 360-389.

8. Kimura, M.; Tokai, T.; Takahashi-Ando, N.; Ohsato, S.; Fujimura, M. Molecular and Genetic Studies of Fusarium Trichothecene Biosynthesis: Pathways, Genes, and Evolution. Biosci. Biotechnol. Biochem. 2007, 71, 2105-2123. [CrossRef]

9. Reino, J.L.; Guerrero, R.F.; Hernández-Galán, R.; Collado, I.G. Secondary metabolites from species of the biocontrol agent Trichoderma. Phytochem. Rev. 2008, 7, 89-123. [CrossRef]

10. Rocha, O.; Ansari, K.; Doohan, F.M. Effects of trichothecene mycotoxins on eukaryotic cells: A review. Food Addit. Contam. 2005, 22, 369-378. [CrossRef]

11. Corley, D.G.; Miller-Wideman, M.; Durley, R.C. Isolation and structure of harzianum a: A new trichothecene from Trichoderma harzianum. J. Nat. Prod. 1994, 57, 422-425. [CrossRef]

12. Pestka, J.J. Deoxynivalenol: Toxicity, mechanisms and animal health risks. Anim. Feed Sci. Technol. 2007, 137, $283-298$. [CrossRef]

13. Martin, L.J.; Doebler, J.A.; Anthony, A. Scanning cytophotometric analysis of brain neuronal nuclear chromatin changes in acute T-2 toxin-treated rats. Toxicol. Appl. Pharmacol. 1986, 85, 207-214. [CrossRef]

14. Brown, D.W.; Dyer, R.B.; McCormick, S.P.; Kendra, D.F.; Plattner, R.D. Functional demarcation of the Fusarium core trichothecene gene cluster. Fungal. Genet. Biol. 2004, 41, 454-462. [CrossRef] [PubMed]

15. Cardoza, R.E.; Malmierca, M.G.; Hermosa, M.R.; Alexander, N.J.; McCormick, S.P.; Proctor, R.H.; Tijerino, A.M.; Rumbero, A.; Monte, E.; Gutiérrez, S. Identification of loci and functional characterization of trichothecene biosynthesis genes in filamentous fungi of the genus Trichoderma. Appl. Environ. Microbiol. 2011, 77, 4867-4877. [CrossRef] [PubMed]

16. Proctor, R.H.; McCormick, S.P.; Kim, H.-S.; Cardoza, R.E.; Stanley, A.M.; Lindo, L.; Kelly, A.; Brown, D.W.; Lee, T.; Vaughan, M.M.; et al. Evolution of structural diversity of trichothecenes, a family of toxins produced by plant pathogenic and entomopathogenic fungi. PLoS Pathog. 2018, 14, e1006946.

17. Nielsen, K.F.; Gräfenhan, T.; Zafari, D.; Thrane, U. Trichothecene production by Trichoderma brevicompactum. J. Agric. Food Chem. 2005, 53, 8190-8196. [CrossRef] [PubMed]

18. Godtfredsen, W.O.; Vangedal, S. Trichodermin, a New Sesquiterpene Antibiotic. Acta Chem. Scand. 1965, 19, 1088-1102. [CrossRef]

19. Westerberg, U.; Bolcsfoldi, G.; Eliasson, E.V.A. Control of tranfer RNA synthesis in the presence of inhibitors of protein synthesis. Biochim. Biophys. Acta 1976, 447, 203-213. [CrossRef]

20. Tijerino, A.; Hermosa, R.; Cardoza, R.E.; Moraga, J.; Malmierca, M.G.; Aleu, J.; Collado, I.G.; Monte, E.; Gutiérrez, S. Overexpression of the Trichoderma brevicompactum tri5 gene: Effect on the expression of the trichodermin biosynthetic genes and on tomato seedlings. Toxins (Basel) 2011, 3, 1220. [CrossRef]

21. Cheng, J.L.; Zhou, Y.; Zhao, J.H.; Zhang, C.; Lin, F.C. Synthesis and antifungal activity of trichodermin derivatives. Chinese Chem. Lett. 2010, 21, 1037-1040. [CrossRef] 
22. Xu, X.; Cheng, J.; Zhou, Y.; Zhang, C.; Ou, X.; Su, W.; Zhao, J.; Zhu, G. Synthesis and antifungal activities of trichodermin derivatives as fungicides on rice. Chem. Biodivers. 2013, 10, 600-611. [CrossRef]

23. Cheng, J.L.; Zheng, M.; Yao, T.T.; Li, X.L.; Zhao, J.H.; Xia, M.; Zhu, G.N. Synthesis, antifungal activity, and QSAR study of novel trichodermin derivatives. J. Asian Nat.Prod. Res. 2015, 17, 47-55. [CrossRef]

24. Colvin, E.W.; Malchenko, S.; Raphael, R.A.; Roberts, J.S. Total Synthesis of ( \pm )-Trichodermin. J. Chem. Soc. Perkin Trans. 1973, 17, 1989-1997. [CrossRef]

25. Still, W.C.; Tsai, M.-Y. Total synthesis of ( \pm )-Trichodermol. J. Am. Chem. Soc. 1980, 102, 3654-3655. [CrossRef]

26. O’Brien, M.K.; Pearson, A.J.; Pinkerton, A.A.; Schmidt, W.; Willman, K. A total synthesis of ( \pm )-Trichodermol. J. Am. Chem. Soc. 1989, 111, 1499-1501. [CrossRef]

27. Ayer, W.A.; Miao, S. Secondary metabolites of the aspen fungus Stachybotrys cylindrospora. Can. J. Chem. 1993, 71, 487-493. [CrossRef]

28. Wei, C.M.; McLaughlin, C.S. Structure-function relationship in the 12, 13-epoxytrichothecenes: Novel inhibitors of protein synthesis. Biochem. Biophys. Res. Commun. 1974, 57, 838-844. [CrossRef]

29. Carrasco, L.; Barbacid, M.; Vazquez, D. The trichodermin group of antibiotics, inhibitors of peptide bond formation by eukaryotic ribosomes. Biochim. Biophys. Acta 1973, 312, 368-376. [CrossRef]

30. Plattner, R.D.; Al-Hetti, M.B.; Weisleder, D.; Sinclair, J.B. A new trichothecene from Trichothecium roseum. J. Chem. Res. 1988, 311, 2461-2473.

31. Langley, P.; Shuttleworth, A.; Sidebottom, P.J.; Wrigley, S.K.; Fisher, P.J. A trichothecene from Spicellum roseum. Mycol. Res. 1990, 94, 705-720. [CrossRef]

32. Tanaka, K.; Plattner, R.D.; Yamagishi, R.; Minamisawa, M.; Manabe, M.; Kawasugi, S.; Gareis, M.; Okada, G. 8-Deoxy-trichothecin production by Spicellum roseum isolated from a cultivated mushroom in Japan. Mycotoxins. 2001, 51, 71-77. [CrossRef]

33. Kralj, A.; Gurgui, M.; König, G.M.; van Echten-Deckert, G. Trichothecenes induce accumulation of glucosylceramide in neural cells by interfering with lactosylceramide synthase activity. Toxicol. Appl. Pharmacol. 2007, 225, 113-122. [CrossRef]

34. Wang, Y.; Zhang, L.; Li, G.-T.; Li, Z.H.; Dong, Z.J.; Li, Y.; Liu, J.K. Identification and Cytotoxic Activities of Two New Trichothecenes and a New Cuparane-Type Sesquiterpenoid from the Cultures of the Mushroom Engleromyces goetzii. Nat. Products Bioprospect. 2015, 5, 47-53. [CrossRef]

Sample Availability: Samples of the compounds $\mathbf{1}$ and $\mathbf{2}$ are available from the authors.

(C) 2019 by the authors. Licensee MDPI, Basel, Switzerland. This article is an open access article distributed under the terms and conditions of the Creative Commons Attribution (CC BY) license (http://creativecommons.org/licenses/by/4.0/). 